\title{
A test of the Lake Habitat Survey method in Cleveland Reservoir and Lake Chivero (Manyame River Basin, Zimbabwe)
}

\author{
Tatenda Dalu1*, Edwin Tambara' ${ }^{2,3}$, Lenin Dzibakwe Chari', Sydney Moyo' and Tamuka Nhiwatiwa ${ }^{2}$ \\ 'Zoology and Entomology, Rhodes University, PO Box 94, Grahamstown 6140, South Africa \\ ${ }^{2}$ Biological Sciences, University of Zimbabwe, PO Box MP 167, Mt Pleasant, Harare, Zimbabwe \\ ${ }^{3}$ Tropical Resources Ecology Program, University of Zimbabwe, PO Box MP 167, Mt Pleasant, Harare, Zimbabwe
}

\begin{abstract}
The Lake Habitat Survey (LHS) method has only been applied once in a tropical African reservoir and could potentially be a useful tool for hydromorphological impact assessments. This study (October 2012) tested the application of the LHS method to two Zimbabwean reservoirs, Cleveland and Chivero, which are impacted differently by human activities within their catchments with varying levels of physical impacts and lakeshore use. The Lake Habitat Quality Assessment (LHQA) and Lake Habitat Modification Score (LHMS) were used to assess the habitat quality and the magnitude of human impact on the reservoirs. Cleveland Reservoir LHQA (78 out of 112) and LHMS (16 out of 42) scores are indicative of relatively low human pressure (e.g. angling and canoeing). Results show that although Cleveland Reservoir is coming under increasing anthropogenic pressure, it does not appear to suffer from major alien plant invasion as compared to Lake Chivero, which scored 62/112 and 32/42 for the LHQA and LHMS, respectively. There were no significant differences between the numbers of vegetation layers in the riparian vegetation of the two reservoirs. However, there were significant differences in the number of macrophyte species and shoreline/riparian pressures between the two reservoirs. In conclusion, the use of the LHS can better enhance quality and reliability of lake hydromorphological assessments in tropical systems, where such an investigation is required to support decision making, after adaptations of the method have been made, i.e., inclusion of catchment impacts on lakes and reservoirs in LHS scoring metrics.
\end{abstract}

Keywords: Lake Habitat Modification Score, Lake Habitat Quality Assessment, human pressure, hydromorphology, catchment

\section{INTRODUCTION}

The importance of lakes and reservoirs for conservation and provision of resources is widely acknowledged; yet a comprehensive procedure for classifying their characteristics and habitat quality is lacking (Rowan et al., 2006; Peterlin and Urbanič, 2013). The hydromorphology of surface waters, along with the water physico-chemical properties, supports all the life functions of the organisms within water bodies. The European Commission Water Framework Directive 2000/60/ EC (European Commission, 2000) introduced the ecological status concept, which is an expression of aquatic ecosystem structure quality and functioning (Ostendorp et al., 2004). The WFD objective has been an important driver in the development of the Lake Habitat Survey (LHS) method that can be used to characterise and assess the physical habitats of lakes and reservoirs.

The LHS approach is based on a combination of a small number of detailed plot observations. It builds upon lake habitat characterisation techniques developed in the United States by the Environmental Mapping and Assessment Program (EMAP) (Kaufmann and Whittier, 1997; Kaufmann et al. 2014), as well as those developed during the UK River Habitat Survey (RHS) (Raven et al., 2000). The LHS method includes quantitative descriptions of vegetation canopy, macrophyte communities, dominant littoral substrate and the impact of human activities on the shoreline (Rowan et al. 2006; Peterlin and Urbanič, 2013; Jusik and Macioł, 2014). The LHS method uses

\footnotetext{
* To whom all correspondence should be addressed. వ +2783 308 7633; e-mail: dalutatenda@yahoo.co.uk Received: 16 July 2014; accepted in revised form 25 November 2015
}

surveys within the terrestrial/aquatic ecotone, which is normally the area incorporating the riparian and littoral zones of a lake. The littoral zone of lentic water bodies is functionally important because it provides shelter against predation and wave action, feeding zones and habitat, and is therefore the zone of highest productivity in a lake (McGoff and Irvine, 2009; Kaufman et al., 2014; Ruhl et al., 2014), but this may not apply universally to man-made water bodies which are often constructed in areas with steep-sloping, rocky terrain. In the lakeshore zone, terrestrial habitats are closely linked with semi-aquatic and lacustrine habitats, giving rise to hydrological gradients and a high habitat diversity. Lakeshores may have many functions in ecology, species and habitat protection, water resource protection, human settlement and welfare, culture and monument preservation, recreation, fishing and tourism (Ostendorp et al., 2004).

The current version of the LHS protocol has already been tested in Zimbabwe (Dalu et al., 2013a), in a remote reservoir minimally impacted by human activities, but there is a need to extend this to reservoirs which are impacted by different human activities, e.g., agriculture, and sewage discharge. In this paper we outline the significance of hydromorphology as an important driver of ecosystem structure and functions in reservoirs. In this study we applied the LHS method to identify the significant human pressures on the lakeshores and tentatively describe the most important impacts resulting from such pressures. This study applied the LHS as a hydromorphological method in 2 tropical reservoirs, which differ in the level of anthropogenic pressures they are exposed to. The LHS could play an important role in standardising condition monitoring in tropical systems, as well as supporting environmental impact assessment and restoration programmes for degraded lake and reservoir ecosystems. The aim of this study was to further test 
the application of the LHS method in a tropical setting using two reservoirs located in an urban setting but with highly contrasting environmental pressures. In that way, the robustness of the LHS method for lake hydromorphological assessments could be tested.

\section{MATERIALS AND METHODS}

\section{Study area}

The Manyame River rises near Marondera town about $65 \mathrm{~km}$ east of Harare and flows in a western direction before turning northward to reach the Zambezi River. The upper Manyame River catchment is economically important as it supplies water to some of the most highly populated areas in Zimbabwe; namely, Harare, Chitungwiza, Norton and Ruwa (Magadza, 1997). Impoundment size is 30 ha for Cleveland and 8100 ha for Chivero (Table 1). Both are susceptible to pollution originating from the city of Harare. With the construction of Lake Chivero in 1953, this reservoir took over the role of water supply from Cleveland and Seke Reservoirs (Tendaupenyu, 2012).

Lake Chivero is located $35 \mathrm{~km}$ southwest of Harare (Fig. 1) and was built as the principal water supplier for the city of Harare (Dalu et al., 2011). The lake has a long history of water quality problems mainly as a result of sewage effluent discharge from Harare and Chitungwiza into its main tributaries (Tendaupenyu, 2012). Cleveland Reservoir was constructed in 1913 and is located within the headwaters of the Mukuvisi River, a tributary of the Manyame River (Fig. 1). The impoundment is surrounded by a protected area/reserve, which serves as a buffer against the impacts of various other land uses in the adjacent urban areas (Ndebele, 2009).

\section{LHS method}

The LHSs of Cleveland Reservoir and Lake Chivero were carried out between 15 and 18 October 2012, with the aid of a boat (Chivero) and on foot (Cleveland). All necessary sampling was carried out during this period, with a single survey for each water body. Physico-chemical variables measured were most representative of the reservoirs' average condition. The LHS surveys were conducted by the same individuals.

A detailed description of the LHS undertaken is provided by Rowan et al. $(2004,2008)$ and Dalu et al. (2013a). Hab-Plots capture detailed information about the physical structure of

\begin{tabular}{|lcc|}
\hline \multicolumn{3}{|c|}{$\begin{array}{c}\text { TABLE 1 } \\
\text { Physical characteristics of the Manyame River Basin } \\
\text { reservoirs. Data from }\end{array}$} \\
$\begin{array}{l}\text { Ndebele (2009) } \\
\text { (2012) }\end{array}$ & and Tendaupenyu \\
\hline Reservoir & Cleveland & Chivero \\
\hline Date of construction & 1913 & 1952 \\
Altitude (m) & 1531 & 1370 \\
Area (ha) & 30 & 2630 \\
Volume $\left(\mathrm{m}^{3} \times 106\right)$ & 1 & 250 \\
Mean depth $(\mathrm{m})$ & 3.3 & 9.5 \\
Catchment $\left(\mathrm{km}^{2}\right)$ & 15 & 2227 \\
\hline
\end{tabular}

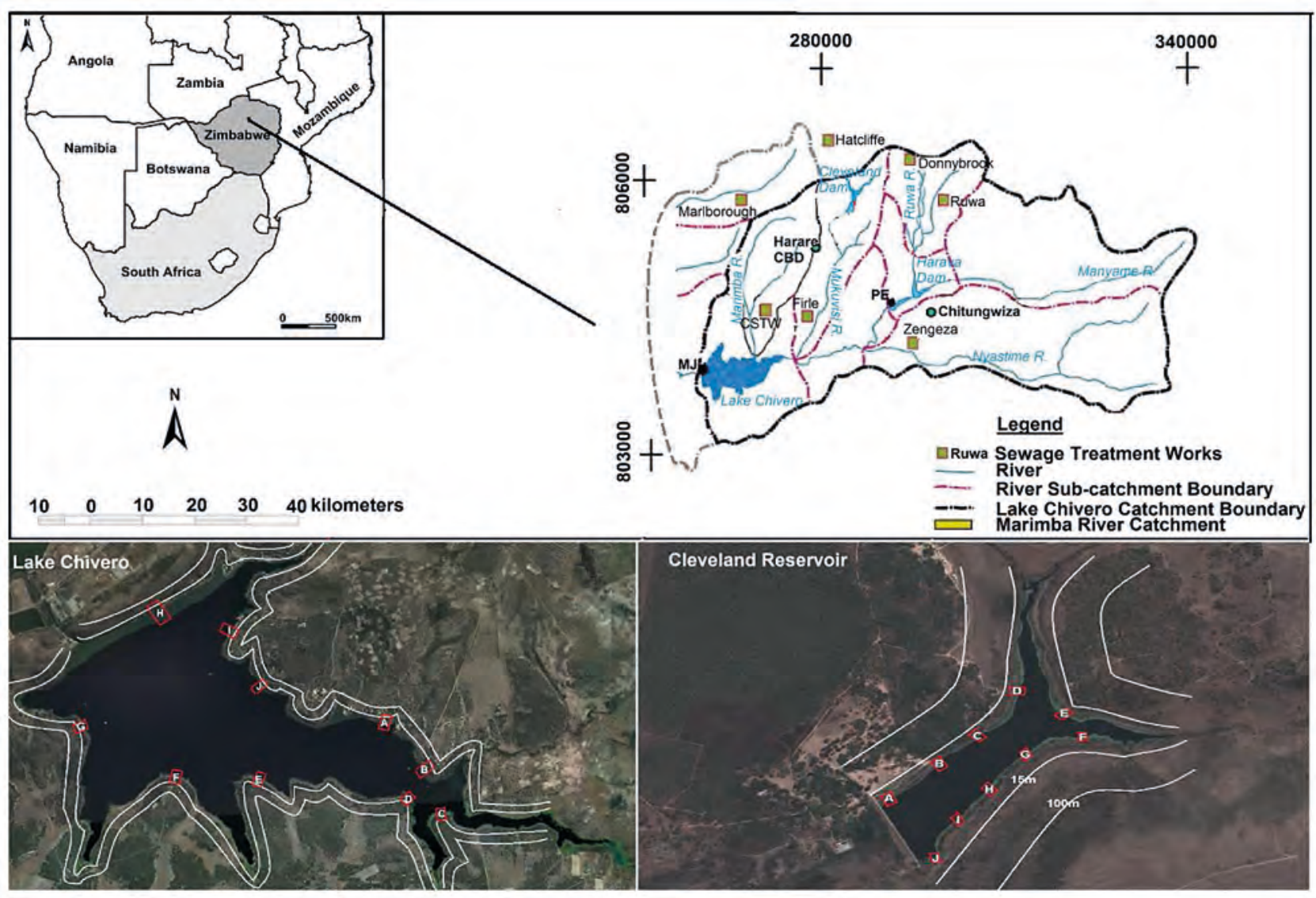

Figure 1

Location of the study areas, Lake Chivero and Cleveland Reservoir, in the Manyame River Basin 
the shore zone (riparian into the littoral) using categorised observations (present/absent or classes of extent) made by the survey team in a boat $10 \mathrm{~m}$ in from the water's edge. Ten of these are typically selected; the first Hab-Plot is located closer to where the boat was launched from and the remainders are approximately evenly spaced around the lake perimeter. Different components which include the littoral zone, shore zone, riparian zone $(15 \mathrm{~m}$ and $50 \mathrm{~m}$ zones landward from the bank top), are recognised, and detailed analyses of morphology, substrate characteristics, vegetation cover and human pressures are made. These detailed observations are complemented by the perimeter survey, which can be carried out directly in the field (Rowan et al., 2006; Dalu et al., 2013a).

Raw and remotely-sensed data from the summer of 1989 and 2001 were obtained using Landsat Thematic Mapper (TM) and a Landsat Enhanced Thematic Mapper (ETM), respectively. Visual interpretation of these enabled comparisons with the present to indicate changes in environmental state and within the reservoir catchments. The registration error for the images was less than 0.4 pixels with a Landsat image resolution of $30 \mathrm{~m}$. Summary metrics of the LHS termed the Lake Habitat Modification Score (LHMS) and the Lake Habitat Quality Assessment (LHQA) were calculated using the survey data.

\section{Lake Habitat Quality Assessment (LHQA)}

The LHQA is based mainly on proportional scoring across habitat observation plots (Hab-Plots); a more detailed description of the LHQA method is described in Rowan et al. (2004). Since this study was confined to 2 reservoirs, the LHQA scoring index, which was designed for comparison across lakes, was adjusted according to Rowan et al. (2006). A minor modification of score ranges was made so as to incorporate nuisance or exotic species. The modified criteria were based firmly on the original LHS approach and philosophy. A perfect score of 112 for LHQA is achieved when the habitat is not impacted in any way.

\section{Lake Habitat Modification Score (LHMS)}

The LHMS is an index of lake hydromorphological alteration, which was developed to synthesize the wide-ranging and multivariate data collected into a meaningful metric (Rowan et al., 2006). The LHMS metric is useful for classification purposes, especially in the identification of lakes and reservoirs with high ecological status and those at risk of not attaining good ecological status due to human activities. Therefore, it enables a comparison of hydromorphological and related pressures such as overfishing, nuisance species, and shoreline modification, amongst others, between different Hab-Plots. The LHMS has a score from 0 to 42 , where the zero end of the scale means that the habitat is natural and has not been modified in any way (high ecological status) while 42 means that the habitats have been greatly impacted (low ecological status).

\section{Basic water quality measurements}

Water was collected at depths of $1 \mathrm{~m}$ and $2 \mathrm{~m}$ intervals for Cleveland Reservoir and Lake Chivero, respectively, for the full vertical profile, using a 10-L Ruttner water sampler at the index site (the deepest point). Measurement of temperature and dissolved oxygen (DO) were done using a $\mathrm{pH}$, conductivity and DO meter (HACH, LDO, Germany). Water transparency was measured using a Secchi disc. Total nitrogen and total phosphorus concentrations were measured in the laboratory with Hach nutrient analysis kits and a Hach spectrophotometer (DR010 Hach Co., Loveland, Colorado, USA). Physicochemical data used in this study for Cleveland Reservoir was obtained from Ndebele-Murisa (2012) studies.

\section{Statistical analysis}

A Kruskal-Wallis Anova analysis $(p<0.05$; using SysStat 12 for Windows version 12.02 .00 (Systat, 2007)), was carried out to test for significant differences in shoreline pressures, riparian vegetation cover and macrophyte species composition among the Hab-Plots and between the two reservoirs, so as to assess the variation in levels of human impact within the different LHS metrics across the two study reservoirs. Pearson and Kendall correlation analyses were performed to investigate the relationship between substrate composition and macrophyte communities among different Hab-Plots within the reservoirs.

\section{RESULTS}

\section{Basic water quality measurements}

The physicochemical data recorded at the index site for the two study reservoirs are summarised in Table 2. Water temperature recorded averaged $24.3^{\circ} \mathrm{C}$ and $21.8^{\circ} \mathrm{C}$ in Lake Chivero and Cleveland Reservoir, respectively. Thermal and dissolved oxygen profiles (Fig. 2) showed that both water systems were stratified. It clear that Cleveland Reservoir was not significantly stratified because there was no oxycline, but there was a pronounced oxycline in Lake Chivero. The thermocline was at $6 \mathrm{~m}$ and $8 \mathrm{~m}$ for Lake Chivero and Cleveland, respectively (Fig. 2a). No algal blooms were observed in Cleveland Reservoir whilst algal blooms were observed in Lake Chivero.

\section{LHS survey}

Summarised data for shoreline pressures and natural shoreline ( $0-15 \mathrm{~m}$ and $>15-50 \mathrm{~m}$ perimeter bands) for each reservoir are presented in Tables 3 and 4 . The Kruskal-Wallis test showed that there were significant differences $(\mathrm{p}<0.05)$ in the shoreline/riparian pressures between the two reservoirs. For Cleveland Reservoir, Hab-Plot C and D recorded the most diverse shoreline with respect to natural land cover types

\begin{tabular}{|l|c|c|}
\hline \multicolumn{3}{|c|}{$\begin{array}{c}\text { TABLE } 2 \\
\text { Summary data for Lake Chivero and Cleveland Reservoir } \\
\text { index sites }\end{array}$} \\
\hline $\begin{array}{l}\text { Measurements at } \\
\text { index site }\end{array}$ & $\begin{array}{c}\text { Lake } \\
\text { Chivero }\end{array}$ & $\begin{array}{c}\text { Cleveland Reservoir } \\
\text { (Ndebele-Murisa, 2012) }\end{array}$ \\
\hline $\mathrm{pH}$ & $7.1-75$ & $7.7-8.66$ \\
\hline Secchi depth (m) & 1 & 3.9 \\
\hline $\begin{array}{l}\text { Temperature range } \\
\left({ }^{\circ} \mathrm{C}\right)\end{array}$ & $23.1-26$ & $21.2-22.3$ \\
\hline $\begin{array}{l}\text { Dissolved oxygen range } \\
\left(\mathrm{mg} \cdot \mathrm{L}^{-1}\right)\end{array}$ & $3.5-7.5$ & $6.6-7.6$ \\
\hline $\begin{array}{l}\text { Total nitrogen range } \\
\left(\mathrm{mg} \cdot \mathrm{L}^{-1}\right)\end{array}$ & $1.16-4.13$ & $0.75-1.28$ \\
\hline $\begin{array}{c}\text { Total phosphorus range } \\
\left(\mathrm{mg} \cdot \mathrm{L}^{-1}\right)\end{array}$ & $2.45-3.99$ & $0.26-0.55$ \\
\hline
\end{tabular}


(a) Temperature $\left({ }^{\circ} \mathrm{C}\right)$

(b)
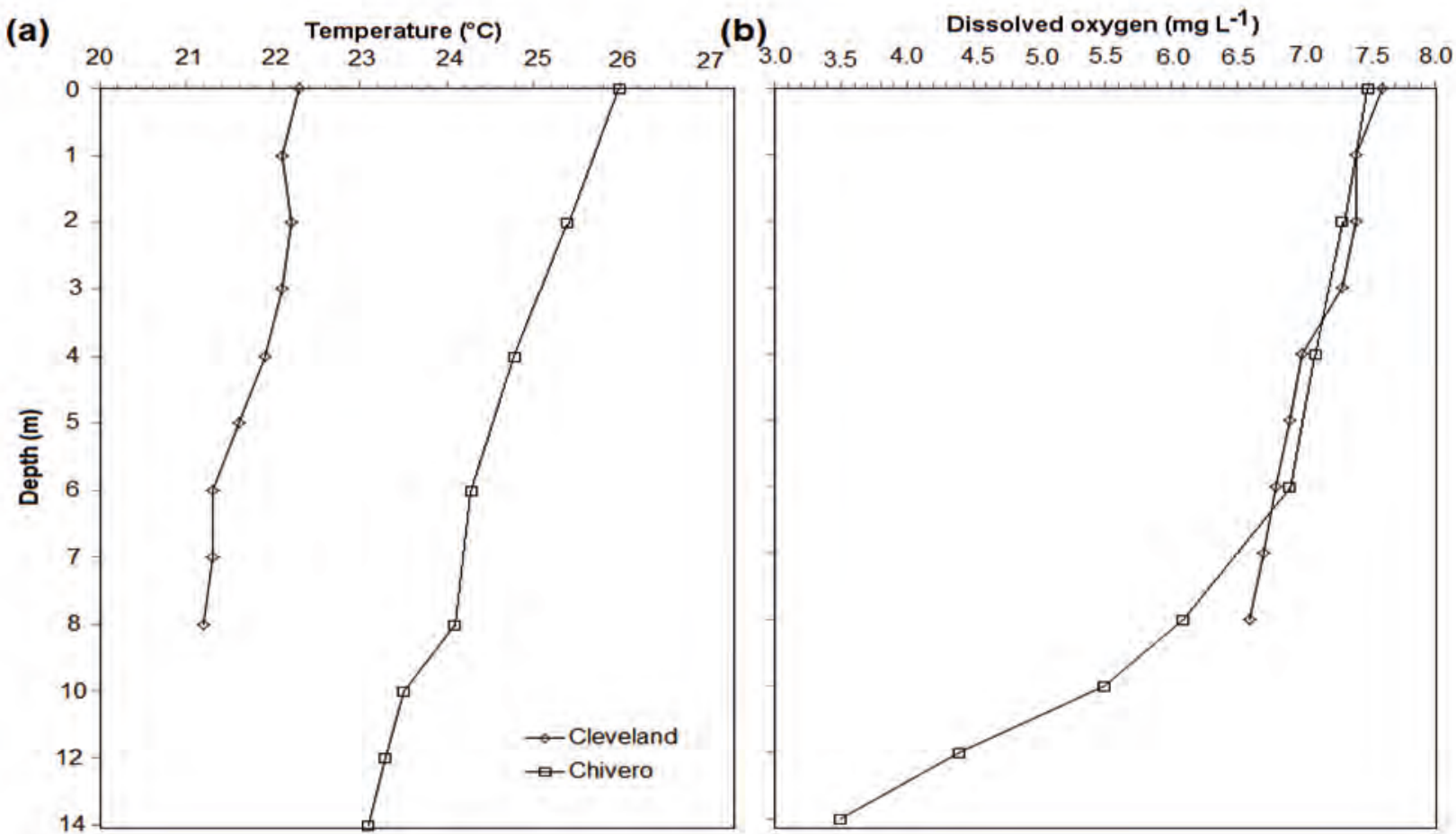

Figure 2

Temperature and dissolved oxygen profiles for Lake Chivero and Cleveland Reservoir

(6 different types), while in Lake Chivero Hab-Plots A-B, $\mathrm{F}-\mathrm{G}$ and $\mathrm{J}$ were the most diverse (6 types each). Lake Chivero's shoreline is dominated by broadleaf/mixed woodland with cover exceeding $40 \%$ and $75 \%$ for the $0-15 \mathrm{~m}$ and $>15-100 \mathrm{~m}$ bands respectively, for almost all of the Hab-Plots. Cleveland Reservoir's shoreline was dominated by rough and unimproved grassland $(>75 \%$ ) for the $0-15 \mathrm{~m}$ band while the $>15-100 \mathrm{~m}$ band was dominated by coniferous/gum tree plantations and broadleaf/mixed woodland (Table 3 and 4).

\section{LHQA and LHMS}

The LHMS scores calculated for the Cleveland Reservoir and Lake Chivero were 16 and 32, respectively (out of 42), while the LHQA scores were 78 and 62, respectively (out of 112) (Tables 5 and 6). Cleveland Reservoir experiences relatively few human pressures, except for non-boat recreation and angling. Lake Chivero scored high on the LHMS and lower on the LHQA. In both reservoirs, there are no tarred roads, only sand roads running through the park and leading to lodges and recreation areas.

\section{Aerial photography}

The use of aerial photography enabled the precise identification and interpretation of the various land use categories in the catchments of the two reservoirs. Bare areas made up only 0.15 $\mathrm{km} 2$ in 1989, showing the highly intensive land use within the catchments. In 2001, there was a significant increase in bare areas (see also Gamanya et al., 2009).

\section{Vegetation}

The different riparian zones found around Cleveland Reservoir and Lake Chivero, mainly the densely vegetated to open

\begin{tabular}{|l|c|c|c|c|}
\hline \multicolumn{5}{|c|}{$\begin{array}{c}\text { TABLE } 3 \\
\text { Summary data for the number of shoreline pressures } \\
\text { within } \mathbf{1 5} \text { m and between } \mathbf{1 5 - 1 0 0} \text { m Hab-Plots for } \\
\text { Cleveland Reservoir (CR) and Lake Chivero (LC) expressed } \\
\text { as extent of total perimeter length }\end{array}$} \\
\cline { 2 - 5 } $\begin{array}{l}\text { Pressures and non-natural } \\
\text { land-use }\end{array}$ & $\mathbf{1 5}$ & $\mathbf{1 0 0}$ & $\mathbf{1 5}$ & $\mathbf{1 0 0}$ \\
\hline Commercial activities & 0 & 0 & 0 & 5 \\
\hline Residential areas & 0 & 0 & 2 & 6 \\
\hline Roads or railways & 0 & 1 & 2 & 6 \\
\hline Parks and gardens & 2 & 1 & 9 & 9 \\
\hline Recreational beaches & 0 & 0 & 0 & 0 \\
\hline Educational activities & 0 & 1 & 5 & 6 \\
\hline Litter, dump, landfill & 0 & 0 & 0 & 0 \\
\hline Quarrying or mining & 0 & 0 & 0 & 0 \\
\hline Evidence recent logging & 1 & 0 & 1 & 2 \\
\hline Pasture & 0 & 0 & 0 & 0 \\
\hline Observed grazing & 0 & 1 & 0 & 0 \\
\hline Improved grassland & 0 & 0 & 2 & 2 \\
\hline Tilled land & 0 & 0 & 2 & 1 \\
\hline Camping and caravanning & 0 & 3 & 4 & 4 \\
\hline Unsealed tracks and pathways & 9 & 10 & 10 & 10 \\
\hline Docks, harbors or marinas & 1 & 0 & 5 & 0 \\
\hline Floating and tethered structures & 0 & 0 & 1 & 2 \\
\hline Hard bank engineering (closed) & 0 & 0 & 1 & 2 \\
\hline Hard bank engineering (open) & 0 & 0 & 5 & 0 \\
\hline Soft bank engineering & 2 & 1 & 4 & 1 \\
\hline Flow and sediment control & 0 & 0 & 3 & 3 \\
\hline Erosion & 0 & 1 & 0 & 4 \\
\hline Number of pressures & 7 & 8 & 16 & 15 \\
\hline
\end{tabular}


TABLE 4

Summary data for the number of natural land cover and meso-habitats within $15 \mathrm{~m}$ and between 15 and100 $\mathrm{m}$ for Cleveland Reservoir (CR) and Lake Chivero (LC), expressed as extent of total shoreline length

\begin{tabular}{|l|c|c|c|c|}
\hline \multirow{2}{*}{$\begin{array}{l}\text { Natural land cover and meso- } \\
\text { habitat type }\end{array}$} & \multicolumn{2}{|c|}{ CR } & \multicolumn{2}{c|}{ LC } \\
\cline { 2 - 5 } Broadleaf/mixed woodland & 1 & 1 & 1 & 1 \\
\hline Broadleaf/mixed plantation & 0 & 0 & 0 & 0 \\
\hline Scrub and shrubs & 1 & 1 & 1 & 1 \\
\hline Wetlands & 1 & 1 & 1 & 1 \\
\hline Open water & 0 & 0 & 0 & 0 \\
\hline Rough grassland & 1 & 1 & 1 & 1 \\
\hline Tall herb/rank vegetation & 1 & 1 & 1 & 1 \\
\hline Rock, scree or dunes & 1 & 1 & 1 & 1 \\
\hline Fringing reed banks & 1 & 1 & 1 & 1 \\
\hline Wet woodlands & 1 & 0 & 0 & 0 \\
\hline Quaking banks & 0 & 0 & 1 & 0 \\
\hline Other (e.g. fern, marsh) & 1 & 0 & 0 & 0 \\
\hline Extent of predominant cover & 9 & 7 & 8 & 7 \\
\hline Diversity of land-cover types & & 9 & & 8 \\
\hline
\end{tabular}

\begin{tabular}{|l|c|c|}
\hline \multicolumn{3}{|c|}{$\begin{array}{c}\text { TABLE 5 } \\
\text { Reservoir (CR) and Lake Chivero (LC) in October 2012 }\end{array}$} \\
\hline Pressure & CR & LC \\
\hline Shore zone modification & 0 & 6 \\
\hline Shore zone intensive use & 2 & 6 \\
\hline In-lake use & 6 & 8 \\
\hline Hydrology & 6 & 6 \\
\hline Sediment regime & 0 & 2 \\
\hline Nuisance species & 2 & 4 \\
\hline LHMS total score & 16 & 32 \\
\hline
\end{tabular}

riparian zones, can be distinguished by different vegetation and substrate types. In Cleveland Reservoir, Hab-Plot A, artisanal fishing (non-motor boat and shore angling) imposes minimal anthropogenic pressures. Macrophyte manipulation and non-boat recreation were observed around the reservoir with other smaller anthropogenic pressures on the reservoir including the small harbour and dysfunctional water extraction/drawing points. In Lake Chivero, non-motor boat, commercial fishing (gillnets), and angling from boat and shore (poaching $>50 \%$ ) were identified in all Hab-Plots A to J. The

\begin{tabular}{|c|c|c|c|c|c|}
\hline \multicolumn{6}{|c|}{$\begin{array}{c}\text { TABLE } 6 \\
\text { Scores for Lake Habitat Quality Assessment (LHQA) for Cleveland Reservoir (CR) and Lake Chivero (LC) in October } 2012\end{array}$} \\
\hline \multirow[t]{2}{*}{ Zone } & \multirow[t]{2}{*}{ Measurable LHS feature } & \multicolumn{2}{|c|}{$\begin{array}{l}\text { Counts of features across lake, or } \\
\text { number of Hab-Plots with a feature }\end{array}$} & \multicolumn{2}{|c|}{ Score allocated } \\
\hline & & CR & LC & CR & LC \\
\hline \multirow{5}{*}{ Riparian } & Complex or simple veg. & 8 & 10 & 4 & 4 \\
\hline & $>10 \%$ large trees & 3 & 10 & 3 & 4 \\
\hline & Natural/semi natural veg. & 10 & 10 & 4 & 4 \\
\hline & No. natural types & 3 & 5 & 4 & 3 \\
\hline & No. bank top features & 3 & 3 & 3 & 2 \\
\hline \multirow{6}{*}{ Shore } & Earth/sand bank & 6 & 5 & 2 & 2 \\
\hline & Trash line & 5 & 4 & 3 & 2 \\
\hline & Natural bank material & 8 & 7 & 4 & 3 \\
\hline & No. natural types & 4 & 3 & 4 & 3 \\
\hline & Natural beach material & 5 & 2 & 0 & 0 \\
\hline & No. natural types & 4 & 1 & 0 & 0 \\
\hline \multirow{8}{*}{ Littoral } & Coefficient variation & 10 & 0 & 4 & 2 \\
\hline & Natural littoral substrate & 10 & 5 & 4 & 0 \\
\hline & No. natural types & 5 & 4 & 4 & 0 \\
\hline & Total macrophyte cover & 10 & 10 & 4 & 4 \\
\hline & Extend lakewards? & 10 & 10 & 4 & 4 \\
\hline & No. macrophyte types & 6 & 7 & 4 & 4 \\
\hline & Total fish cover & 10 & 10 & 4 & 4 \\
\hline & No. littoral features & 5 & 4 & 2 & 3 \\
\hline \multirow{3}{*}{ Whole lake } & No. wetland habitats & 4 & 2 & 15 & 5 \\
\hline & No. islands & 0 & 4 & 0 & 5 \\
\hline & No. deltaic deposits & 0 & 0 & 0 & 0 \\
\hline Vegetation structure & Introduced species & 3 & 7 & 2 & 4 \\
\hline \multicolumn{4}{|l|}{ Total } & 78 & 62 \\
\hline
\end{tabular}


impact of introduced (exotic) species was clearly visible, as well as the impact of macrophyte manipulation and nonboat recreation. Algal mats were evident as a result of sewage entering the lake through the Marimba and Manyame Rivers.

The vegetation in the areas surrounding Cleveland Reservoir was mainly comprised of plantations of Eucalyptus species and miombo woodland. Brachystegia spiciformis and Julbernardia globiflora were the most dominant species in the miombo woodland around both Cleveland Reservoir and Lake Chivero. Woody shrubs and grasses were dominant in the marginal areas of both reservoirs. Bryophytes (ferns) were also observed in Hab-Plot J at the Cleveland Reservoir. Estimates of aerial cover for the different vegetation groups found within the riparian zones for the different Hab-Plots (A-J) are shown in Table 7. The aquatic plants found at Cleveland Reservoir were Cyperus sp., Panicum repens, Phragmites mauritianus, Potamogeton sp., Nymphaea sp., Elodea sp. and Schoenoplectus corymbosus. Lake Chivero was dominated by Eichhornia crassipes, Hydrocotyle ranunculoides, Potamogeton crispus, Cyperus sp. and Phragmites spp. High macrophyte frequencies $(>75 \%)$ among the dominant species in Lake Chivero were observed in all Hab-Plots (A-J), extending lakewards, while Cleveland Reservoir was dominated by Nymphaea sp. and Elodea sp., which were found in high frequencies along the eastern littoral zone (Hab-Plots G-J) and north-east to north-west (Hab-Plots D-H). Kruskal-Wallis Anova tests showed that there were no significant differences $(p>0.05)$ in the riparian vegetation cover among the different Hab-Plots, but there were significant differences $(p<0.05)$ in the macrophyte species between the two reservoirs.

Refugia for fish and invertebrates were abundant in both reservoirs due to the presence of high levels of macrophyte cover in the littoral zone in traditional nursery habitats. Substrate in the drawdown zone in Lake Chivero was dominated by silt/clay with Hab-Plots B, C, E and H consisting of bedrock, boulders, cobbles, and sand (Table 8). In Lake Chivero, silt/clay consisting of fine organic substrates was the most dominant substrate found throughout the whole lake. Hab-Plots A, C-D, and F-J consisted of bedrock, boulders, cobbles and sand in that reservoir. Bedrock outcrops and boulders were frequent along the southern shoreline (HabPlot D) closer to the mouth (Table 8). Pearson and Kendall correlations $(R=0.86)$ showed a strong positive relationship between substrate composition and macrophyte species communities among the different Hab-Plots.

\begin{tabular}{|c|c|c|c|c|c|c|c|c|c|c|c|c|c|c|c|c|c|c|c|c|}
\hline \multicolumn{21}{|c|}{$\begin{array}{l}\text { TABLE 7 } \\
\text { Variations in vegetation cover for the different Hab-Plots (A-J) within the riparian zone. } \\
0=0 \%, *=0-1 \%, 1=>1-10 \%, 2=>10-40 \%, 3=>40-75 \%, 4=>75 \% ;+=\text { present }\end{array}$} \\
\hline \multirow{2}{*}{ Physical attributes } & \multicolumn{2}{|c|}{ A } & \multicolumn{2}{|c|}{ B } & \multicolumn{2}{|c|}{ C } & \multicolumn{2}{|c|}{ D } & \multicolumn{2}{|c|}{$\mathbf{E}$} & \multicolumn{2}{|c|}{$\mathbf{F}$} & \multicolumn{2}{|c|}{ G } & \multicolumn{2}{|c|}{$\mathbf{H}$} & \multicolumn{2}{|c|}{ I } & \multicolumn{2}{|c|}{ J } \\
\hline & CR & LC & CR & LC & CR & LC & CR & LC & CR & LC & CR & LC & CR & LC & $\mathrm{Cr}$ & LC & CR & LC & CR & LC \\
\hline \multicolumn{21}{|l|}{ Canopy layer (>5 m) } \\
\hline Trees $\geq 0.3 \mathrm{~m}$ diameter & 0 & 1 & 2 & 0 & 1 & 0 & 0 & 2 & * & 0 & 0 & 1 & 0 & 0 & 0 & 0 & 0 & 3 & 0 & 1 \\
\hline Trees $<0.3 \mathrm{~m}$ diameter & 3 & 3 & 2 & 0 & 1 & 3 & * & 2 & 2 & 1 & 0 & 2 & 0 & 2 & 0 & 3 & 1 & 3 & 0 & 3 \\
\hline \multicolumn{21}{|l|}{ Under storey $(0.5-5 \mathrm{~m})$} \\
\hline Woody shrubs and saplings & 0 & 2 & 2 & 2 & 1 & 0 & * & 1 & 2 & 1 & * & 1 & 2 & 0 & 1 & 1 & 2 & 1 & * & 2 \\
\hline Tall herbs and grasses & 0 & 3 & 1 & 3 & 3 & 3 & 4 & 0 & 3 & 3 & 4 & 2 & 3 & 4 & 3 & 2 & 3 & 2 & 3 & 2 \\
\hline \multicolumn{21}{|l|}{ Ground cover $(<0.5 \mathrm{~m})$} \\
\hline Woody shrubs and seedlings & 0 & 2 & 2 & 2 & 1 & 1 & * & 0 & 2 & 1 & * & 0 & 2 & 1 & 1 & 2 & 2 & 1 & * & 2 \\
\hline Herbs, grasses, bryophytes & 1 & 2 & 1 & 2 & 2 & 2 & 2 & 0 & 3 & 2 & 4 & 2 & 3 & 2 & 3 & 1 & 3 & 3 & 3 & 4 \\
\hline Notable nuisance plant species & + & & + & & & & & & & & & & & & & + & + & + & & + \\
\hline Extent of non-native species & 3 & & 1 & & & & & & & & & & & & & 1 & 1 & 1 & & 1 \\
\hline
\end{tabular}

\section{TABLE 8}

Substrate characteristics found in the different Hab-Plots (A-J) for the littoral zones using the LHS form. $0=0 \%, *=0-1 \%, 1=>1-10 \%, 2=>10-40 \%, 3=>40-75 \%, 4=>75 \%$

\begin{tabular}{|c|c|c|c|c|c|c|c|c|c|c|c|c|c|c|c|c|c|c|c|c|}
\hline \multirow{2}{*}{ Littoral substrate texture } & \multicolumn{2}{|c|}{ A } & \multicolumn{2}{|c|}{ B } & \multicolumn{2}{|c|}{ C } & \multicolumn{2}{|c|}{ D } & \multicolumn{2}{|c|}{$\mathbf{E}$} & \multicolumn{2}{|c|}{$\mathbf{F}$} & \multicolumn{2}{|c|}{ G } & \multicolumn{2}{|c|}{$\mathbf{H}$} & \multicolumn{2}{|c|}{ I } & \multicolumn{2}{|c|}{ J } \\
\hline & CR & LC & CR & LC & CR & LC & CR & LC & CR & LC & CR & LC & CR & LC & CR & LC & CR & LC & CR & LC \\
\hline Bedrock & 0 & 4 & 1 & 0 & 0 & 2 & 0 & 0 & 0 & 0 & 0 & 1 & 0 & 0 & 0 & 0 & 0 & 0 & 0 & 0 \\
\hline Boulders (>256 mm) & 0 & 3 & 2 & 0 & 2 & 4 & 0 & 1 & 0 & 0 & 0 & 0 & 0 & 1 & 2 & 0 & 0 & 1 & 0 & 2 \\
\hline Cobbles $(>64-256 \mathrm{~mm})$ & 0 & 2 & 1 & 0 & 0 & 2 & 0 & 0 & 0 & 0 & 0 & 0 & 0 & 0 & 0 & 4 & 0 & 3 & 0 & 2 \\
\hline Pebbles $(>2-64 \mathrm{~mm})$ & 0 & 1 & 0 & 0 & 0 & 0 & 0 & 0 & 2 & 0 & 0 & 0 & 0 & 0 & 0 & 2 & 0 & 2 & 0 & 1 \\
\hline Sand $(>0.063-2 \mathrm{~mm})$ & 0 & 2 & 0 & 0 & 0 & 0 & 0 & 0 & 2 & 0 & 0 & 0 & 0 & 0 & 0 & 2 & 0 & 1 & 0 & 1 \\
\hline Silt/clay $(<0.063 \mathrm{~mm})$ & 4 & 3 & 2 & 4 & 4 & 0 & 4 & 3 & 3 & 4 & 4 & 2 & 4 & 4 & 4 & 2 & 4 & 2 & 4 & 3 \\
\hline
\end{tabular}




\section{DISCUSSION}

\section{LHS survey}

The LHMS metric, which uses expert opinion to define thresholds of hydromorphological pressures leading to likely impacts on 'ecological status', showed that Cleveland Reservoir was less impacted by hydromorphological pressures compared to Lake Chivero. Cleveland Reservoir scored 10/42 whilst the less protected Lake Chivero scored 32/42 (Table 5) Lake Chivero is impacted by raw sewage and industrial effluent, fish poaching, shoreline activities, lodges, macrophyte manipulation, invasive species (e.g. water hyacinth, water pennywort, Nile tilapia) and recreational pressures (Table 3). Lake Chivero is located downstream of Harare and Chitungwiza; hence its main tributaries (Manyame, Marimba and Mukuvisi Rivers) are heavily polluted, unlike Cleveland Reservoir which has few housing developments in its catchment as was evident from aerial photography (see Gamanya et al. 2009) and hence is experiencing minimal degradation and pollution.

The LHQA metric is configured to express naturalness and diversity as proxies for the conservation value of a site. Cleveland Reservoir scored 78/112 suggesting that the reservoir still has a more natural environment that is not heavily impacted by human influences, as compared to Lake Chivero (62/112) (Table 6). Cleveland Reservoir ranked slightly higher than Malilangwe Reservoir which is situated in a nature conservancy (LHQA = 76/112) (Dalu et al., 2013a), which clearly shows that it is still relatively unimpacted. It should however be pointed out that, although the LHQA shows a higher value for Cleveland Reservoir compared to Lake Chivero, the LHQA score for the reservoir does not conside that it is one of Zimbabwe's Important Bird Areas (IBA) and supports large numbers of fish-eating birds, waterfowl and migratory species. The density of woodland bird species surrounding the lake is higher than at Cleveland Reservoir, possibly because of the lake flies that emerge in huge numbers. It also supports populations of other animals, such as Clawless Otters Aonyx capensis, that are under pressure elsewhere in the country. Hence, we propose to include this important parameter, i.e., designation as a protected area such as an IBA, for other LHS studies across the country.

Decreases in the mean substrate size and increases among the different Hab-Plots in the percentage of fine sediments ( $>75$ \%) were observed in Cleveland Reservoir (mostly Hab-Plots A and $\mathrm{C}-\mathrm{J}$ ), and also Lake Chivero (Hab-Plots A-B, C-D and G) (Table 8). This may also indicate increases in the rates of upland erosion and sediment supply. These substrate characteristic changes are often sensitive indicators of the effects of human activities on streams in the catchment, which in turn affect reservoirs. Substrate particles and characteristics are one of the most important determinants of habitat characteristics for fish and macroinvertebrates, along with bed form (Kaufmann and Whittier, 1997). The sudden increase in illegal urban agriculture in the City of Harare due to socio-economic and political circumstances in the country is clearly a major factor contributing to siltation, as poor farming methods are often practised.

Many of the habitats in the Cleveland Reservoir littoral zones are of a seasonal or ephemeral nature, due to evaporation and drawdown, which results in yearly water depth decreases of between 2-3 m or more. This usually results in decreases in macrophyte abundance. Macrophytes harbour macroinvertebrates and fish (Dalu et al. 2012); thus decreasing macrophyte abundance can possibly result in changes in the aquatic ecosystem (T Dalu, personal observation). It is also known that, within a single lake, vegetated sites often support a greater diversity of macroinvertebrates than do open water sites (Brendonck et al., 2003). However, the case is different for Lake Chivero whose main tributaries, Manyame, Marimba and Mukuvisi Rivers are now perennial rivers due to sewage and industrial effluent inflows; hence the lake has in recent years always been $>80 \%$ full. The lake level is highly variable, and the present situation may not be permanent ( $>80 \%$ full). The lake level can fall drastically in drought years, as in 1967-68, 1972-73 and the early 1990s; the fish kill in 1996 described by Moyo (1997) followed 5 years of drought when the lake volume had fallen to approx. $20 \%$ of its capacity but then filled in about 6 weeks after very heavy rains, This produced massive blooms of algae and stands of water hyacinth along with intense deoxygenation caused by decomposition of the drowned vegetation that had grown on the exposed shores.

\section{LHS and aerial photography}

According to Rowan et al. (2006), aerial imagery should be prepared and analysed before the field survey and should be taken as a printed map to the field to aid the filling of the LHS survey form. From the study observations, we strongly recommend the use of aerial photography with very high resolution for LHS surveys. Skocki et al. (2008) showed that better resolution permits the interpretation of different classes, borders and buffer zone ranges in more detail. It is recommended that aerial photography should be used in the assessment of the 15-100 $\mathrm{m}$ buffer zones and the different riparian and littoral zones, as it proved to be very helpful in its initial use in Malilangwe Reservoir (Dalu et al., 2013a).

\section{LHS and catchments impacts}

There has been expansion in residential areas mainly to the south and south-west of Harare between 1989 and 2000 and this has further exacerbated the problems affecting Lake Chivero as the new residential areas are not properly serviced, hence lack water and wastewater reticulation systems (Gamanya et al., 2009). Increased urban agriculture combined with discharge of loads of untreated sewage into the Lake Chivero tributaries further resulted in an increase in nutrient loads in Lake Chivero (Table 7, see also Gamanya et al. 2009). No major changes were observed for Cleveland Reservoir catchment hence this might explain the general good health observed for the reservoir. These highlighted changes in the catchment might affect the results of the LHS survey as the catchment activities are not part of the LHS survey but appear to cause significant impacts in comparison to lakeshore activities.

\section{Basic water quality measurement status}

Dissolved oxygen (DO) levels for Lake Chivero dropped from $7.5 \mathrm{mg} \cdot \mathrm{L}^{-1}$ at $0 \mathrm{~m}$ depth to $3.5 \mathrm{mg} \cdot \mathrm{L}^{-1}$ at $14 \mathrm{~m}$ depth for the index site (Fig. 2), which was an indicator of oxygen depletion; near the lake mouth DO levels of less than $1 \mathrm{mg} \cdot \mathrm{L}-1$ have been recorded. This probably means that stratification is sufficient to limit water exchange between the surface and bottom water during summer. It is known that DO levels below $4 \mathrm{mg} \cdot \mathrm{L}^{-1}$ cause acute mortality of macroinvertebrates and plankton 
communities (Moyo, 1997; Chick et al., 2004; Mhlanga et al., 2006; Moyo, 2012), and therefore these results indicate that there is a major problem in the lake. Deoxygenation of bottom waters and the resultant changes in redox potential at the sediment-water interface lead to a rapid release of nutrients and contaminants, resulting in significant water quality deterioration, especially at turnover. This has resulted in fish deaths in Lake Chivero following a heavy inflow of pollutants from the catchment. The fish deaths always coincide with the collapse of an algal bloom that will have developed and built up in the lake for about 8 months, and which reduces dissolved oxygen to below $1.9 \mathrm{mg} \cdot \mathrm{L}^{-1}$ from $5 \mathrm{~m}$ depth (Moyo, 1997; Mhlanga et al., 2006; T. Dalu, personal observation). This is an issue of concern which requires the institution of appropriate management measures, because as the severity of algal blooms in the lake increases more fish kills may occur when the algal blooms collapse. Another important factor leading to fish deaths could be algal toxins that will have been released into the system following the collapse of the algal bloom (Mhlanga et al., 2006).

The differences in temperature of up to $4^{\circ} \mathrm{C}$ could be related to several factors such as the physics of water and changes in its density at high temperatures (Marshall and Falconer, 1973). Dalu et al.'s (2013b) study in Malilangwe Reservoir (Zimbabwe) suggests that increases in temperature will result in high water heat budgets, which could potentially trigger changes in aquatic population dynamics, with severe water quality implications. These water quality changes as a result of increases in water temperature, in both reservoirs, will have a more significant impact on the nutrient-rich Lake Chivero than on Cleveland Reservoir.

Algal blooms observed in Lake Chivero could be attributed to the high nutrient levels which cause low water transparency in Lake Chivero (Table 2). Low dissolved oxygen concentrations and odours indicative of hydrogen sulphide and ammonia are evident in Lake Chivero, especially towards the river mouth ( $\mathrm{T}$ Dalu, personal observation), and these are indicative of hydrogen sulphide and ammonia. Cleveland Reservoir, in particular, could be in danger of contamination by pollutants due to increased cultivation, deforestation and settlements within the catchment, though currently it has good water quality as indicated by the physicochemical data. The lessons learned from the pollution of Lake Chivero can be used to curb the pollution in Cleveland Reservoir.

\section{Critique of the LHS method}

The LHS method may prove to be an important tool in hydromorphological assessment but the method has its drawbacks in tropical African regions. The LHS method gives insufficient attention to the extreme water level regime of tropical reservoirs, which as a result of the tropical climate has a pronounced wet season followed by extended dry periods when water is used for irrigation and drinking water. This results in the shore zone experiencing extreme wetting and drying cycles and consequently producing a distinctive (very sparse) vegetation community, with macrophytes being unlikely to thrive and ruderal and amphibious species doing better. The water drawdown as evidenced by the 'bath-tub rings' in most tropical water systems suggests that the littoral zone will be a relatively hostile environment for macrophytes and co-dependent biota (see Dalu et al. 2012). Hence, it will be useful to include all these factors in the LHS and also to analyse the littoral slopes from survey data and determine whether substrate, littoral slope and macrophytes are correlated. It is vital to realise that the lakes under investigation are reservoirs and that there are many important factors influencing the distribution and abundance of macrophytes such as the functional groups from Hab-Plots, and how these patterns respond to variations in substrate, water depth, wave exposure and water level fluctuations. All of these features are not factored into the LHS method, with potentially serious implications for the success of its application; we therefore suggest the inclusion of a section dedicated to water level fluctuations and macrophyte communities for tropical lakes and reservoirs. Equating the draw-down zone of a reservoir to a natural beach is erroneous for tropical systems, as the characteristics of draw-down zones are temporary, depending on the reservoir operation rules, while lakeside beaches, such as those on Lakes Malawi and Victoria, have evolved over thousands of years of land and water interface. We therefore suggest the removal of beaches from the LHS method when applied to tropical reservoirs.

Similarly to other studies (e.g. McGoff and Irvine (2009), Peterlin and Urbanič (2013) and Jusik and Macioł (2014)), future studies must be carried out focusing on specific HabPlot analyses that include detailed reporting of the substrate, littoral slopes, macrophyte assemblages or riparian vegetation. Immediate riparian pressures are relatively limited in tropical systems with a few exceptions being cities and towns around Lakes Victoria and Malawi where population is increasing exponentially (UNEP, 2006). Some of the riparian shoreline pressures, e.g., commercial activities, coniferous plantations, orchards, logging and recreational beaches, are features associated with highly developed countries' landscapes and urban areas and are either absent or rare in developing countries' reservoirs. These attributes are designed to assess the impact of proximity of development to lakes or reservoirs, and should be used with caution for tropical systems. Thus, the inclusion of such riparian pressures does not warrant being included for LHSs in tropical systems. Major impacts arise some considerable distance from the 15 to $100 \mathrm{~m}$ limit, which is an arbitrary limitation as most of the impacts on tropical systems are experienced in the catchment. In natural lakes such a zone could have unique riparian features but not in tropical reservoirs. A detailed section on catchment activities or impacts should thus be included.

The LHS method further takes into account the outlet from the lake or reservoir, but there is no indication on what part inflows play, and what the effect of intermittent seasonal flow is. All these important factors should be included as several studies, e.g. Kim et al. (2000) and Lai et al. (2014), have highlighted the importance of river inflows for reservoirs. Criteria such as presence of alders and coniferous forest are not applicable to tropical systems; hence for this and future studies, alders and coniferous forest were not considered, and were substituted by local vegetation where applicable.

In this study, $10 \mathrm{Hab}$-Plots were found to be adequate for describing lake habitat characteristics. Similarly, Rowan et al. (2006) and Dalu et al. (2013a) reported that relatively little information is gained if more than $10 \mathrm{Hab}$-Plots are sampled as having more plots increases the survey time and introduces undesirable redundancy in the data collected. It must be noted, however, that the number of Hab-plots needed is dependent on the size of the water body and the diversity of its habitats. In the tropics no other methods are known to have been used to assess the scale of human impact in the form of developmental pressures around lakes and reservoirs; the LHS method will continue to be an essential tool for the assessment of human impacts on lakes. 


\section{Management and policy}

Based on this broader experience from field trials in more impacted reservoirs, it is anticipated that LHS could contribute to the development of a standard for assessing the hydromorphology of standing waters under the aegis of the CEN, Water and Environment Acts of Zimbabwe. The LHS can play a pivotal role in the research and monitoring of the lakes and reservoirs in Zimbabwe, but more studies need to be carried out to see whether it can be used as a standard monitoring tool for lakes and reservoirs.

\section{CONCLUSION}

This study shows that the LHS method has potential as a hydromorphological impact assessment and management tool that integrates several variables related to human pressures on aquatic ecosystems. Good water governance has been regarded as a sine qua non for improving the management of world water resources; hence we anticipate that the LHS will play a pivotal role in hydromorphological assessments of lakes and reservoirs if it is incorporated as part of policy. The case of Lake Chivero and Cleveland Reservoir is a good example of how hydrological changes, in combination with poor governance, urban population growth and lack of anticipatory management can cause an environmental crisis such as eutrophication resulting in fish deaths. Nhapi (2004) concluded that there is a tendency toward 'over-research' in the area of pollution, but that the manifestation of suggested remedial actions and recommended measures has largely been ignored in Zimbabwe. Therefore, the state should be at the forefront of water resources management and should include all stakeholders in this process.

\section{ACKNOWLEDGEMENTS}

We will like to extend our deepest appreciation and thank you to the editor and anonymous reviewers for their valuable input into this study. Special thanks go to Harare City Council Amenities Division (Parks Section) and the Zimbabwe Parks and Wildlife Management Authority for granting us permission to work at Cleveland Reservoir and Lake Chivero, respectively. Our appreciation also goes to the Department of Biological Sciences, University of Zimbabwe, for all their technical support during the study.

\section{REFERENCES}

BRENDONCK L, MAES J, ROMMENS W, DEKEZA N, NHIWATIWA T, BARSON M, CALLEBAUT V, PHIRI C, MOREAU K, GRATWICKE B, STEVENS M, ALYN N, HOLSTERS E, OLLEVIER F and MARSHALL BE (2003) The impact of water hyacinth (Eichhornia crassipes) in a eutrophic subtropical impoundment (Lake Chivero, Zimbabwe). II. Species diversity. Arch. Hydrobiol. 158 389-405. http://dx.doi. org/10.1127/0003-9136/2003/0158-0389

CHICK JH, RUETZ CR and TREXLER JC (2004) Spatial scale and abundance patterns of large fish communities in freshwater marshes of the Florida Everglades. Wetlands 24 652-664. http://dx.doi. org/10.1672/0277-5212(2004)024[0652:SSAAPO]2.0.CO;2

DALU T, BARSON M and NHIWATIWA T (2011) Impact of microbial organisms and protozoan parasites on drinking water quality in Harare, Zimbabwe. J. Water Sanit. Hyg. Dev. 1 153-163. http:// dx.doi.org/10.2166/washdev.2011.049

DALU T, CLEGG B and NHIWATIWA T (2013a) Application of the Lake Habitat Survey method on the tropical Malilangwe reservoir, south-east Lowveld, Zimbabwe. Afr. J. Aquat. Sci. 38 21-35. http:// dx.doi.org/10.2989/16085914.2012.716362

DALU T, CLEGG B and NHIWATIWA T (2012) Aquatic macrophytes in a tropical African reservoir: diversity, communities and the impact of reservoir-level fluctuations. Trans. R. Soc. S. Afr. 67 117-125. http://dx.doi.org/10.1080/0035919x.2012.712554

DALU T, MOYO S, CLEGG BW and NHIWATIWA T (2013b) Stratification, diel and seasonal energy transfers of Malilangwe Reservoir in the south-eastern lowveld of Zimbabwe. Lakes Reserv. Res. Manage. 18 285-296. http://dx.doi.org/10.1111/lre.12039

EUROPEAN COMMISSION (2000) Directive 2000/60/EC of the European Parliament and of the Council establishing a framework for the Community action in the field of water policy - EU Water Framework Directive (WFD). The European Parliament And The Council Of The European Union, Brussels, Belgium.

GAMANYA R, DE MAEYER P and DE DAPPER M (2009) Objectoriented change detection for the city of Harare, Zimbabwe. Expert Syst. Appl. 36 571-588. http://dx.doi.org/10.1016/j.eswa.2007.09.067

JUSIK S and MACIOŁ A (2014) The influence of hydromorphological modifications of the littoral zone in lakes on macrophytes Oceanol. Hydrobiol. Stud. 43 66-76.

KAUFMANN PR, HUGHES RM, VAN SICKLE J, WHITTIER TR, SEELIGER CW and PAULSEN SG (2014) Lakeshore and littoral physical habitat structure: A field survey method and its precision. Lake Reserv. Manage. 30 157-176. http://dx.doi.org/10.1080/104023 81.2013.877543

KAUFMANN PR and WHITTIER TR (1997) Habitat assessment. In: Baker JR, Peck DV and Sutton DW (eds) Environmental Monitoring and Assessment Program Surface Waters: Field Operations Manual For Lakes. EPA/620/R-97/001. United States Environmental Protection Agency, Washington, DC.

KIM B, CHOI K, KIM C, LEE U-H and KIM Y-H (2000) Effects of the summer monsoon on the distribution and loading of organic carbon in a deep reservoir, Lake Soyang, Korea. Water Res. 34 3495-3504. http://dx.doi.org/10.1016/S0043-1354(00)00104-4

LAI X, HUANG Q, ZHANG Y and JIANG J (2014) Impact of lake inflow and the Yangtze River inflow alterations on water levels in Poyang Lake, China. Lake Reserv. Manage. 30 321-330. http:// dx.doi.org/10.1080/10402381.2014.928390

MACHENA C (1997) The pollution and self-purification of Mukuvisi River. In: Moyo NAG (ed.) Lake Chivero: A Polluted Lake. University of Zimbabwe Publications, Harare. 75-91.

MAGADZA CHD (1997) Water pollution and catchment management in Lake Chivero. in: Moyo NAG (ed.) Lake Chivero: A Polluted Lake. University of Zimbabwe Publications, Harare. 13-26.

MANZUNGU E and MABIZA C (2004) Status of water governance in urban areas in Zimbabwe: some preliminary observations from the city of Harare. Phys. Chem. Earth 29 1167-1172. http://dx.doi. org/10.1016/j.pce.2004.09.003

MARSHALL BE (1994) Ecology and management of the Manyame lakes. In: Matiza T and Crafter SA (eds) Wetlands Ecology and Priorities for Conservation in Zimbabwe. IUCN, Gland. 55-68.

MARSHALL BE and FALCONER AC (1973) Physico-chemical aspects of Lake McIlwaine (Rhodesia), a eutrophic tropical impoundment. Hydrobiologia 42 45-62. http://dx.doi.org/10.1007/BF00014145

McGOFF E (2008) Invertebrate-habitat associations in the littoral and riparian ecotone of Lough Carra, Co. Mayo, Ireland: non-technical summary. Freshwater Ecology Research Group, Trinity College, Dublin.

McGOFF E and IRVINE K (2009) A test of the association between Lake Habitat Quality Assessment and macroinvertebrate community structure. Aquat. Conserv. Mar. Freshwater Ecosyst. 19 520-533. http://dx.doi.org/10.1002/aqc.1024

MHLANGA L, DAY J, CHIMBARI M, SIZIBA N and CRONBERG G (2006) Observations on limnological conditions associated with a fish kill of Oreochromis niloticus in Lake Chivero following collapse of an algal bloom. Afr. J. Ecol. 44 199-208. http://dx.doi. org/10.1111/j.1365-2028.2006.00625.x

MOYO NAG (1997) Causes of massive fish deaths in Lake Chivero. In: Moyo NAG (ed.) Lake Chivero: A Polluted Lake. University of Zimbabwe Publications, Harare. 
MOYO S (2012) A comparative study on aspects of ecology of zooplankton in Lake Chivero and Mazvikadei Dam, Zimbabwe. MSc thesis. University of Zimbabwe, Harare.

NDEBELE MR (2009) Primary production and other limnological aspects of Cleveland Dam, Harare, Zimbabwe. Lakes Reserv. Res. Manage. 14 151-161. http://dx.doi. org/10.1111/j.1440-1770.2009.00395.x

NDEBELE-MURISA MR (2012) Biological monitoring and pollution assessment of the Mukuvisi River, Harare, Zimbabwe. Lakes Reserv. Res. Manage. 17 73-80. http://dx.doi. org/10.1111/j.1440-1770.2012.00497.x

NHAPI I (2004) Options for wastewater management in Harare, Zimbabwe. PhD thesis, Wageningen University, Wageningen, The Netherlands.

OSTENDORP W, SCHMIEDER K and JÖHNK K (2004) Assessment of human pressures and their hydromorphological impacts on lakeshores in Europe. Int. J. Ecohydrol. Hydrobiol. 4 229-246.

PETERLIN M and URBANIC G (2013) A Lakeshore Modification Index and its association with benthic invertebrates in alpine lakes. Ecohydrol. 6 297-311. http://dx.doi.org/10.1002/eco.1269

RAVEN PJ, HOLMES NTH, NAURA M and DAWSON FH (2000) Using river habitat survey for environmental assessment and catchment planning in the U. K. Hydrobiologia 422-423 359-367. http:// dx.doi.org/10.1023/A:1017026417664

ROBARTS RD, THORNTON JA and WATTS CJ (1982) Phytoplankton, primary production and nutrient limitation, In: Thornton JA (ed.) Lake McIlwaine: The Eutrophication and Recovery of a Tropical African Lake. Dr W Junk Publishers, The Hague.

ROWAN JS, DUCK RW, CARWARDINE J, BRAGG OM, BLACK AR and CUTLER MEJ (2004) Development of a technique for Lake Habitat Survey (LHS): Phase 1. Report for SNIFFER
Project (WFD40). Scotland and Northern Ireland Forum for Environmental Research (SNIFFER), Edinburgh.

ROWAN JS, CARWARDINE J, DUCK RW, BRAGG OM, BLACK AR, CUTLER MEJ, SOUTAR I and BOON PJ (2006) Development of a technique for Lake Habitat Survey (LHS) with applications for the European Union Water Framework Directive. Aquat. Conserv. Mar. Freshwat. Ecosyst. 16 637-657. http://dx.doi.org/10.1002/aqc.786

ROWAN JS, SOUTAR I, BRAGG OM, CARWARDINE J and CUTLER MEJ (2008) Lake Habitat Survey in the United Kingdom field survey guidance manual version 3.1. Final Report Project WFD 42. Scotland and Northern Ireland Forum for Environmental Research (SNIFFER), Edinburgh, pp. 4-36. RUHL N, SOSKI JJ and ROOSENBURG WM (2014) Spatial variation in the littoral vertebrate community of a reservoir relative to physical and biological gradients. PeerJ 2 e693.

SKOCKI K, SOSZKA H, GOŁUB M and KOLADA A (2008) Aerial imagery as a supporting tool in hydromorphological assessment of Górskie Lake, Poland. Limnol. Rev. 8 183-190.

SYSTAT (2007) Mystat: A student version of Systat 32-bit UNICODE English. Version 12.02.00. SYSTAT Software, Inc., Chicago.

TENDAUPENYU P (2012) Nutrient limitation of phytoplankton in five impoundments on the Manyame River, Zimbabwe. Water SA 38 97-108. http://dx.doi.org/10.4314/wsa.v38i1.12

UNEP (2006) United Nations Environment Programme Africas lakes: atlas of our changing environment. UNEP Division of Early Warning and Assessment, Washington, DC.

ZENGEYA TA and MARSHALL BE (2007) Trophic interrelationships amongst cichlid fishes in a tropical African reservoir (Lake Chivero, Zimbabwe). Hydrobiologia 592 175-182. http://dx.doi. org/10.1007/s10750-007-0790-7 